\title{
The Debate on Social Welfare in Western Developed Countries
}

\author{
Wenxi $\mathrm{Xu}^{1, *}$ \\ ${ }^{1}$ Liaoning Normal University, Dalian, Liaoning, China \\ *Corresponding author. Email: Xu126121@163.com

\begin{abstract}
With the development of global economy, the shortcomings of social welfare system in western developed countries are gradually exposed. Social welfare system has become a hot topic in today's society. Therefore, this paper first analyzes the status quo of social welfare system in western developed countries. Secondly, this paper discusses the views of scholars who support and oppose social welfare. Finally, the paper discusses the impact of high welfare on national economy.
\end{abstract}

Keywords: western developed country, social welfare system, welfare state, long-term unemployment rate

\section{INTRODUCTION}

Limited research is being done by scholars and researchers concerning the impact of social welfare on economic development in most developed countries. According to Jungsub Shin, "average welfare spending levels in most advanced industrial democracies are now between 20 and 28 percent of GDP". (qtd. in "Organization for Economic Co-operation and Development" 430) The question is why do the proportions of social welfare expenditures in most developed countries make up for almost three-tenths of the country's GDP? What is the economic impact of such a high proportion of government social welfare expenditure? Social welfare in western developed countries is always an argumentative topic in today's society. People argue the impact of social welfare on economic development.

\section{DIFFERENT SCHOLARS' VIEWS ON SOCIAL WELFARE IN WESTERN DEVELOPED COUNTRIES}

\section{A. Scholars with positive views}

James Griffin outlines that the reason for high social welfare expenditures in most developed countries is because "welfare rights are often classed as 'positive' rights, in contrast to 'negative' rights such as not being prevented from choosing one's own goals (autonomy) and not being interfered with in their pursuit (liberty)" (28). He points out that social welfare is regarded by most developed countries as the progress of a country. He states that social welfare not only guarantees people's freedom but also guarantees people to pursue their goals.

\section{B. Scholars with negative views}

According to Lene Aarøe and Michael Bang Petersen, the active social welfare system in most western developed countries may "reinforce the effect of the laziness" (694). In other words, he means that active social welfare makes people lazy. Because social welfare is so good, people can live without working hard. Laziness directly affects the economic development of companies and countries. Assar Lindbeck mentions that "if we do not watch out for hazardous dynamics, there is a risk that the welfare state will destroy its own economic foundations" (9). He notes that western countries welfare systems have disadvantages. He thinks that if western developed countries do not pay attention to the harmful effects of the welfare, the welfare system will seriously damage the country's economy. According to Paul de Beer and Ferry Koster, with the development of today's modern society, "individualization and globalization render the welfare state unsustainable in the long run" (219). Paul de Beer and Ferry Koster describe that "individualization and globalization" (219) make competition among countries fiercer. They think that welfare makes the whole country unable to adapt to today's global development, and welfare is not good for the long-term development of the country. Although the welfare system brings "social rights" to citizens, "social rights" can also "legitimize the very inequalities which markets produced" (Moran 399). He means that the defects of welfare in most western developed countries make the market more unfair. Citizens have too many rights are not good for market management. 


\section{THE ECONOMIC IMPACT OF SOCIAL WELFARE}

\section{A. People who support social welfare}

1) Social welfare system promotes redistribution: In the article entitled "The Multidimensionality of Welfare State Attitudes: A European Cross-National Study", Femke Roosma et al. state that the main goal of welfare is to achieve social equity through the secondary distribution of income and resources. Welfare system alleviates injustice in society, so that people in the society can earn money in an equal position. Social equity plays an important role in the development of the country's economy, so social welfare is beneficial to the healthy development of the national economy. For example, Roosma states that in a competitive market, in order to allocate "scarce resources" (qtd. in Roemer 237), society need to distribute or "redistribute" (237) resources fairly. Roosma also tell us with the development of "democratization" and "industrialization", making "redistribution a matter of justice and an urgent societal problem" (qtd. in Fleischaccker 237). The emergence of welfare aims to solve the unfair problems in the process of national economic development through "redistribution" (237). Redistribution "[reallocates] life chances by giving people equal opportunities and a certain socio-economic status" (237). He mentions that in today's modern society, the redistribution of resources in welfare state is of great significance to social justice. The welfare state applies the fairness to every distribution of society in an effort to make people believe in the fairness of the system. The goal of the welfare is to give everyone equal rights, and fair redistribution gives people more chances to develop economic throughout the process of welfare system.

2) Social welfare system brings vitality to the market: What's more, Roomsa tells us in recent decades "welfare policies emphasise activation of people for the labour market or other forms of societal participation" (239). People have working passion can help to transfer "welfare to workfare" (239). He explains to us that social welfare brings energy to the market by promoting social equity. Social equity let people not be treated unfairly in the workplace, so people will be more energetic in the work. If people are lazy in their work, even if more people participate in production, it will still not promote the development of the company. Only when people's work is active, the country's economy can develop. Therefore, social welfare is beneficial to the healthy development of the national economy. Welfare aims to make people generally benefit, so welfare system does lots of effort to promote social justice. Social justice plays an important role in the development of country's economy.

\section{B. People who are against social welfare}

1) Social welfare system increases unemployment: Firstly, social welfare reduces the number of employees, thus reducing the company's output, which eventually slows down the speed of national economic development. With fewer productive people in society, the country's economy will no longer growing. In "Welfare State Institutions and Labor Market Trends," Dr. Martin Ehlert, a researcher at the Berlin Social Science Center, points out that unemployment payments in the United States "coverage of almost all industries-leading to a wide variety of unemployment compensation policies throughout the country" (70). From his words, we can see that the country's social welfare gives unemployed people in various industries "unemployment compensation" (Ehlert 70), so that people do not have to worry about their survival after losing their jobs. For example, Ehlert states that in Germany, "[s]ince 1998, the unemployed receive 67 per cent of their former monthly net wages if they live with children and 60 per cent if they live without children" (71). Ehlert uses data to prove to us that if the unemployed people don't work, they can still get more than half of their original salary. People in welfare countries do not have to worry about being unable to live without work, because if they are unemployed, they can receive subsidies from their countries. Above we can see that if there are more people who are not working in the society, this will not only increase the government's subsidy cost, but also reduce the company's output. Robert H. Haveman, a professor of economics at University of Melbourne, states that "in both the United States and Western Europe, the longduration unemployment rate has been secularly increasing" (44). He points out that the problem of increasing number of unemployed people is common in developed welfare countries. The reason why we research the relationship and impact of welfare policy on the "unemployment rate" is because the welfare policy plays an important role in "dealing with the labor market" (Rueda et al. 296). In addition, Rueda's point of view prefers to support that "the welfare state today remains a powerful buffer between unemployment and inequality" (296). He thinks that the main reason for unemployment is because of welfare policy. Due to welfare policy, unemployment situation in welfare state will be more severe. A lot of unemployed people will cause fewer people in the companies to provide goods. With fewer companies providing goods, the economic level of the country will naturally decrease, which 
eventually slows down the speed of national economic development. Therefore, with fewer productive people in society, the country's economy is no longer growing. High social welfare will eventually be harmful to the economy.

2) Social welfare system increases government burden: Secondly, social welfare increases the government's financial spending, which eventually slows down the speed of national economic development. With the increasing proportion of social welfare spending in government finances, government's financial pressure will continue to increase and its economy will continue to decrease. According to Claus Offe, a professor emeritus of political sociology at the Hertie School of Governance, "welfare state has become too heavy a burden on the economy, the growth potential and competitiveness of which are consequently seen to suffer from the excessive costs and rigidities" (504). In other words, he points out that government huge social welfare spending actually increases the production cost of companies. If the production cost is too high, companies will lose profit. As a result, companies have to stop production. Companies stop production will slow down the development of the welfare state economy. What's more, government huge financial spending is not good for the healthy development of the economy. Greece is a typical country, so let's take Greece as an example. Sofia Vasilopoulou and Daphne Halikiopoulou state that "since the eruption of the eurozone crisis in late 2009, Greece has plunged into deep recession" (14). They argue that Greek government's huge welfare spending leads the country's economy to be in a big trouble. Vasilopoulou and Halikiopoulou state that "austerity measures increase taxes on income and property, sales taxes rise from 19 percent to 23 percent, and the tax-free threshold for income has lowered significantly. All sectors of the population suffered, especially the middle class" (14). They mean that because Greece's current economic situation is bad, and Greek government is not wealthy, so Greek government has to takes measures to increase government revenue and reduce people's consumption by raising taxes. Increasing taxes by Greek government causes a decline in living standards for almost all Greeks, and many people become poor as a result. Increasing taxes will cause Greece's economy even worse. During the time of economic difficulty, "Greek citizens increasingly lost their trust in the system," and "the legitimacy of the system is called into question" (Vasilopoulou and Halikiopoulou 15). Greek government has to collect taxes from people's daily consumption and production in order to pay for welfare. A large part of benefits of people's production are used to pay taxes to the government, which makes people's live difficult and country's economic in danger. Because the economy of welfare state is not energetic, companies and individuals will find it hard to make money. Therefore, social welfare will eventually slow down the speed of national economic development. High social welfare is harmful to the economy.

3) Social welfare system reduces market efficiency: Social welfare system actually imposes great pressure on the development of companies and the national economy. Welfare makes the country's market poor efficiency, which seriously blocks country's economic progress. For example, according to data from Femke Roosma's survey of 22 European countries in 2008, Roosma says that "the European public is most critical about the welfare state's effectiveness: About 50-60\% perceive substantial abuse and underuse of welfare benefits" (243). He mentions that more than half of the people in European society think that the efficiency level of their countries is very low. People from 22 European countries also believe that country does not allocate welfare properly. Some people may try to get more benefits provided by the government to avoid their responsibilities, and at the same time some people may not fully enjoy the convenience of welfare. The lack of proper allocation benefits in the welfare state will make people realize that welfare leads to social injustice, which is contrary to the goal of the welfare. Also, according to data from Femke Roosma's survey of 22 European countries in 2008, Roosma says that there is a "relatively high correlation of 0.538 between the dimensions efficiency and outcomes-policy" (244). This result shows "an inefficient system will cause poor policy outcome" (244). He wants to tell us that the efficiency of a country has a great impact on the results of a national policy. According to the first example above, we see that welfare can lead to inefficiency, and from this example we can continue to see that inefficiency can make the government's policies worse. The failure to implement government policies is not conducive to the healthy development of the country. Roomsa says "such disappointment with the welfare state's outcomes may lead to decreasing legitimacy" (244). Welfare does not achieve the expected results. The legal effect of welfare has declined, and people no longer believe that welfare can bring justice to society and promote economic progress. Therefore, social welfare system actually imposes great pressure on the development of companies and the national economy. Welfare makes the market poor efficiency, which seriously blocks country's economic progress. 


\section{CONCLUSION}

To sum up, in the face of global competition in today's society, the impact of high social welfare on economic development has always been a controversial topic. Western developed countries' social welfare system has the characteristics of equalization, universalization, high fiscal expenditure, and government burden. The political system of a country is closely related to its economy. Nowadays, a group of people question the legitimacy of the system. High welfare is a double-edged sword, so how to maintain high welfare under the background of capital globalization still needs to be tested.

\section{References}

[1] Aarøe, Lene, and Michael Bang Petersen. "Crowding Out Culture: Scandinavians and Americans Agree on Social Welfare in the Face of Deservingness Cues." The Journal of Politics, vol. 76, no. 3, 2014, pp. 684-697.

[2] De Beer, Paul, and Ferry Koster. "Between Community Care and European Welfare State: Policy Alternatives for the National Welfare State." Sticking Together or Falling Apart?: Solidarity in an Era of Individualization and Globalization, Amsterdam University Press, 2009, pp. 219-232.

[3] Ehlert, Martin. "Welfare State Institutions and Labor Market Trends." The Impact of Losing Your Job: Unemployment and Influences from Market, Family, and Stateon Economic WellBeing in the US and Germany, Amsterdam University Press, 2016, pp. 69-82.

[4] Griffin, James. "Welfare Rights." The Journal of Ethics, vol. 4, no. $1 / 2,2000$, pp. 27-43.

[5] Haveman, Robert H. "Unemployment in Western Europe and the United States: A Problem of Demand, Structure, or Measurement?" The American Economic Review, vol. 68, no. 2, 1978, pp. 44-50.

[6] Lindbeck, Assar. "Hazardous Welfare-State Dynamics." The American Economic Review, vol. 85, no. 2, 1995, pp. 9-15.

[7] Moran, Michael. "Crises of the Welfare State." British Journal of Political Science, vol. 18, no. 3, 1988, pp. 397-414.

[8] Offe, Claus. "Democracy against the Welfare State?: Structural Foundations of Neoconservative Political Opportunities." Political Theory, vol. 15, no. 4, 1987, pp. 501-537.

[9] Roosma, Femke, et al. "The Multidimensionality of Welfare State Attitudes: A European Cross-National Study." Social Indicators Research, vol. 113, no. 1, 2013, pp. 235-255.

[10] Rueda, David. "The State of the Welfare State: Unemployment, Labor Market Policy, and Inequality in the Age of Workfare." Comparative Politics, vol. 47, no. 3, 2015, pp. 296-314.

[11] Shin, Jungsub. "The Consequences of Government Ideology and Taxation on Welfare Voting." Political Research Quarterly, vol. 69 , no. 3, 2016, pp. 430-443.

[12] Vasilopoulou, Sofia, and Daphne Halikiopoulou. "Greek Politics: Economic Crisis or Crisis of Democracy?" World Affairs, vol. 178, no. 3, 2015, pp. 13-18. 